\title{
DYNAMICS OF MAIN INDICATORS OF THE CANADIAN BANKING SYSTEM
}

Maryna Korol'

\begin{abstract}
Relevance of research. During the global financial collapse of 2008-2009, Canadian banks demonstrated stability and vastly avoided the international crisis. There was a view that Canada's banking system was strict and overly risk-oriented, but after the crisis, it was recognized as logical in terms of lending, which required careful government supervision and regulation based on the principles of security and reliability. In fact, the World Economic Forum recognizes Canadian banks as the most stable in the world. So, all mentioned above prompted us to study the dynamics of the main indicators of the Canadian banking system. The aim of the study is to summarize and characterize the existing trends of banking system evolution in Canada. Methodological basis of the study is based on the analysis of the study of the Canadian banking system according to the indicators of the number of banking institutions, their profitability / loss, the quality of the loan portfolio and analysis of the largest banks in the country. A systemic analysis of the quantitative and qualitative composition of the above-mentioned banking indicators, synthesis and generalization were used to generalize and formulate conclusions. Scientific results. This article is devoted to the study of the dynamics of the main indicators of the Canadian banking system during the period from 2000 to 2019 inclusively. It is argued that the number of commercial banks has had a positive dynamics during the analyzed period, even the period of the global financial crisis of 2008-2009 has not reduced their number, which indicates the stability and prudent policy of commercial banks and the Central Bank as a whole. It has been established that 2019 is the year of the historical maximum assets of the Canadian banking system (more than 277\% of Canada's GDP). It is shown that the assets of eight largest banks in Canada account for $91 \%$ of the total assets of the banking sector. A record decline in the bank's profits was recorded in 2009. The quality of the loan portfolio of commercial banks in Canada since 2009 shows a significant decrease in the share of outstanding loans. The practical significance of the study is to rate the strengths and weaknesses of the Canadian banking system. Significance / originality. The results achieved form an integrated view of the functioning of the Canadian banking system. The following studies will focus on methods and models for verifying the stability of banking systems, including the Canadian banking system.
\end{abstract}

Key words: banks, banking system, assets and liabilities of commercial banks, quality of loan portfolio of commercial banks.

JEL Classification: E51, E59, G21, G34

\section{Introduction}

The Canadian financial system is largely a product of the banking model developed by Alexander Hamilton, the first US Treasury Secretary. Adam Short, a historian-economist who wrote a series of articles for the Journalists of the Canadian Association of Bankers at the turn of the twentieth century, went so far as to call Hamilton "the father of the Canadian banking system". Today, the Canadian banking model remains true to Hamilton's ideal. The main idea was that the links between financially oriented structures at the national level and the government under any normal political conditions

\footnotetext{
Corresponding author:

${ }^{1}$ Uzhhorod National University, Ukraine.

E-mail:maryna.korol@uzhnu.edu.ua

ORCID: https://orcid.org/0000-0003-4031-0858
}

would gain stability, inspire trust and respect within the state and abroad.

We share the view of scientists who argue that the relative stability of Canadian banks during the recent crisis compared to the United States reflected the original institutional foundations laid in the early nineteenth century. The Canadian concentrated banking system, which developed by the end of the twentieth century, absorbed key sources of systemic risk - the mortgage market and investment banking - and was tightly regulated by a single general regulator in contrast to the relatively weak, fragmented and crisis-prone US banking system (Bordo, Redish \& Rockoff, 2011). 
Stability of Canadian banks during the financial crisis can be explained by the fact that, in Canada, the banking system has been built on the basis of large financial institutions, scale and diversification of which have strengthened their resilience, while the US system is fragmented, creating small and vulnerable financial institutions, while developing a powerful market and a confusing set of rules for financial institutions.

However, there are scholars who argue that despite the fact that the Canadian banking system is more resilient in times of crisis than the US, in the context of market banking, the winning position is occupied by the US banks (Calmes, Théoret, 2013).

So, what is the secret of the Canadian banking? According to L. Booth (Booth, 2009), the ultimate secret is that the heads of all Canadian banks are commercial bankers, not investment bankers, so the focus remains on mutual banking.

The above-mentioned works of scientists and many other works have inspired the study of the dynamics of the Canadian banking system.

\section{Number of Banks and Departments of the Canadian Banking System}

The need to adapt to changing circumstances and opportunities is not new to the Canadian banking system. For almost two centuries, the development of the system involved: geographical expansion, consolidation of the industry, expansion of a wide range of financial services, etc.

Canada has a mature, competitive and centrally regulated banking system, the government of which believes that there should be a clear distinction between the financial services sector and the commercial sector of the economy.

The current state of the Canadian banking system can best be understood and interpreted by studying the dynamics of its indicators such as the number of banking institutions, their profitability/loss, the quality of the loan portfolio and analysis of the largest banks in the country. The country's eight largest banks have developed significant business, opened branches in foreign countries, including the West Indies. This is partly due to the commercial relations established there, and partly due to the nature of the Canadian economy (active export and import trade has made them a significant trader in foreign currency).

In general, Canadian banks have survived the financial crisis much better than most of their international competitors.

Thus, based on the data shown in Figure 1, in 2019, there were 85 financial institutions in the country, 53 of them were domestic banks and subsidiaries of foreign banks, the number of the latter increased by $43 \%$ during the study period. Even the period of the financial crisis of 2008-2009 did not affect the decrease in the number of banks, which indicated a balanced policy of commercial banks and the Central Bank in general.

Regarding the number of branches, since 2014, there has been a negative trend, a decrease of $7.21 \%$. However, $42 \%$ of all branches operate in Ontario.

What concerns Ontario, it is the national financial center of Canada, with about 12,000 firms offering a wide range of financial services, from retail banking and lending, capital management and payment processing. Banks make up the largest part of the Ontario financial services segment. Having one of the highest concentrations of banks, capital markets and insurance companies in the world, Ontario is a center of Canada's financial services (Ontario Canada, 2019).

In 2018, Canada's six largest banks managed 5,578 branches in the country, which is $2.9 \%$ less than ten years ago. Although the decline is not as dramatic as once predicted by those who believed that ATMs and mobile banking would stop the spread of traditional branches and affiliates, the number of which does not correlate with population growth. However, it is still an important part of banking, and in Canada, the two largest lenders are putting pressure on competitors, increasing

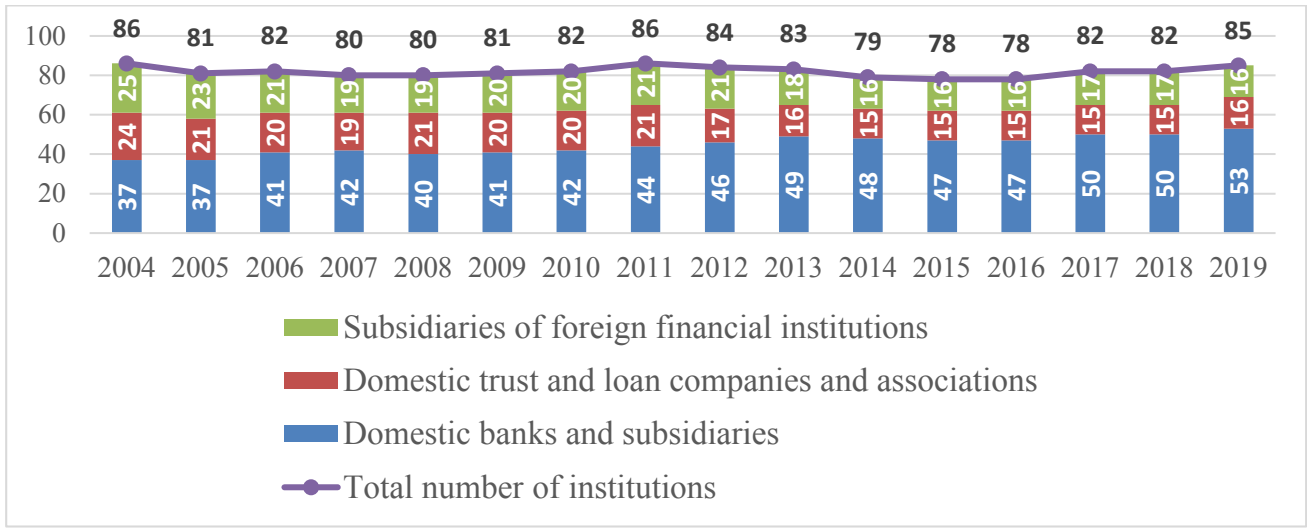

Figure 1. Dynamics of the Total Number of Canada's Financial Institutions, 2004-2019

Source: compiled by authors based on materials of the CDIC (CDIC, 2009; CDIC, 2015; CDIC, 2020) 


Yukon
NWT/Nunavut
British Columbia
Alberta
Saskatchewan
Manitoba
Ontario
Quebec
New Brunswick
Prince Edward Island
Nova Scotia
Newfoundland
Total banks' branches

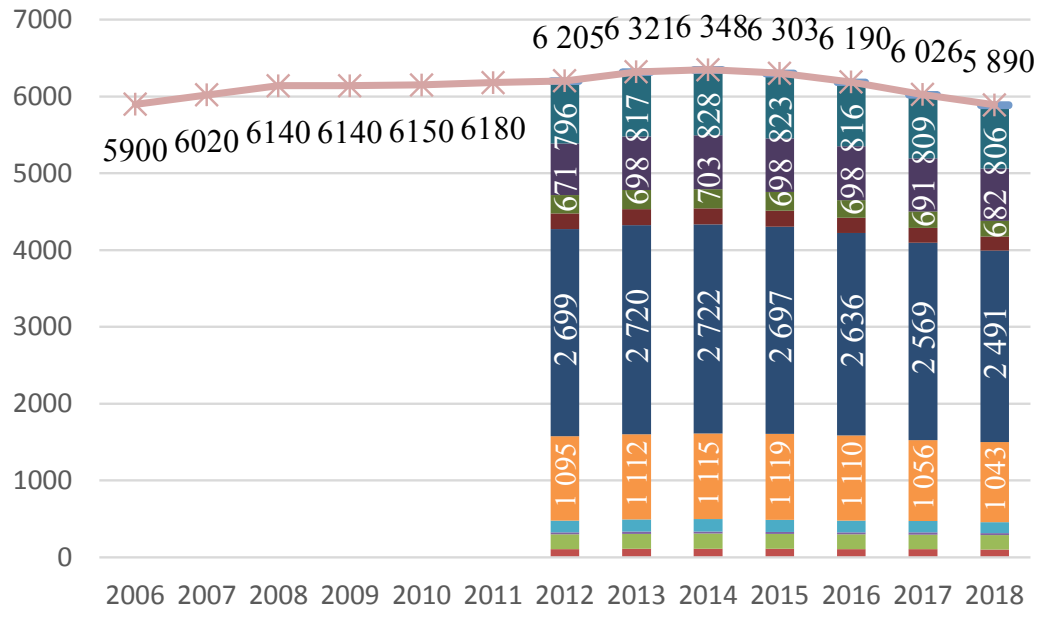

Figure 2. Dynamics of the Number of Branches, 2006-2018

Source: compiled by authors based on materials of the Canadian Bankers Association, Szmigiera (Canadian Bankers Association, 2020; Szmigiera, 2020)

profits per branch. The Royal Bank of Canada and the Bank of Toronto-Dominion earn \$14 million a year from each of their internal branches, outpacing competitors. Scotia earned \$11 million, CIBC - \$10.2 million, BMO $\$ 9.2$ million and National Bank - $\$ 8.2$ million.

As of 2018, Canada had 20 branches for every 100,000 adults, which less comparing to about 25 of them before the 2008 financial crisis, according to the World Bank. In comparison, the number of branches in the United States was 31 per 100,000 adults, and in 2008 - 35 (Doug, 2019).

\section{Assets and Liabilities}

\section{of the Canadian Banking Sector}

At the end of December 2019, the total assets of Canadian banks amounted to $\$ 6.4$ trillion (Figure 3), which is more than $277 \%$ of Canada's GDP (forecast). Thus, Canada's assets reached a new all-time high, and the lowest level was recorded - 104\% of GDP in 1988. Canada ranked 10th out of 96 countries in terms of banking assets as a share of GDP, 20 places above the position observed 10 years ago. Canada's average GDP growth rate from 2000-2019 is 8\% (Helgi Analytics, 2019).

It should be noted that the share of assets of the eight largest banks in Canada in 2019 account for $91 \%$ of total assets. However, their share during the study period increased from $88 \%$ to $91 \%$.

At the end of 2019, the share of assets in the national currency in banks' portfolios was $47 \%$ or $\$ 2.97$ trillion, $7 \%$ down. The volume of assets in foreign currency for the same period showed

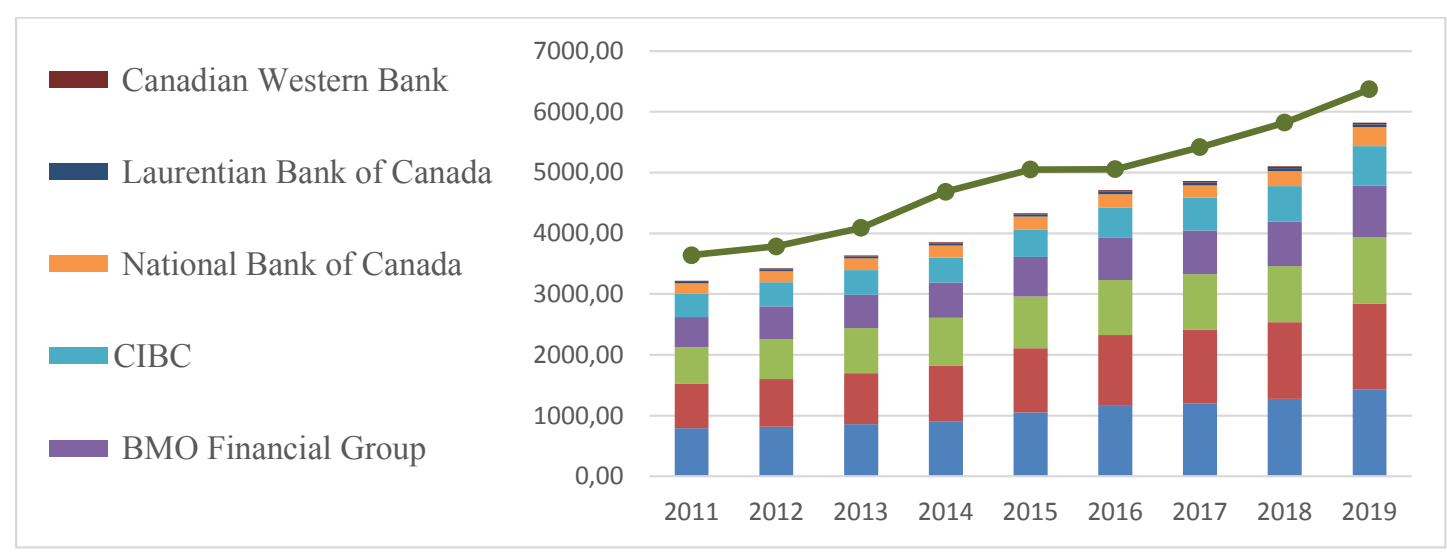

Figure 3. Dynamics of Canadian Banking Sector Assets, 2011-2019

Source: compiled by authors based on materials of the Canadian bankers association, Banks around the World, Bank of Canada (Canadian bankers association, 2018; Banks around the World, 2019; Bank of Canada, 2020) 
an increase of $29 \%$ and amounted to $53 \%$ or $\$ 3.403$ trillion (Bank of Canada, 2020 в).

In 2019, the largest share in the asset portfolio in Canadian dollars is occupied by mortgages, which amounted to $\$ 1.31$ trillion. The volume of housing mortgages at the end of 2019 increased by $37 \%$ and amounted to $41 \%$ of the total portfolio of assets and $19 \%$ of assets in national currency. The share of corporate mortgages was $6 \%$, and the share of total assets and assets in Canadian dollars was $3 \%$ and $1 \%$, respectively (Bank of Canada, 2020 a).

The total amount of loans in Canada's asset portfolio is $64 \%$ and has been in this range since 2002 (2002 - 57\%, 2010 - 55\% (Bank for International Settlements, 2018). Securities account for $19 \%$ of commercial banks' assets at the end of 2019, of which foreign currency securities have the largest share - 14\% (Bank of Canada, 2020 a).

Individual loans have the largest share in the total value of loans in the national currency at the end of 2019 , which amounted to $\$ 528.61$ billion or $18 \%$ and $8 \%$ of assets in national currency and in total assets, respectively. Also other loans have high share, including interim financing or "bridge financing" designed to cover short-term business needs, which amounted to $\$ 375.27$ billion and amounted to $13 \%$ and $6 \%$ of total assets in national currency and total assets, respectively (Bank of Canada, 2020 a).

Regarding the liabilities of commercial banks, during the period under study there is a relatively positive dynamics (Figure 4).

The financial crisis of 2008-2009 did not have an extremely negative effect on the liabilities of commercial banks, reducing total volumes by only $5 \%$. Thus, the liabilities of commercial banks in 02.2020 increased 4 times compared to 2000 . Regarding their structure, starting from 2019, the largest share is occupied by demand deposits of individuals.

\section{Net Income of Banks in the Canadian Banking System}

Regarding the net profits of banks, their record decrease was recorded in 2009 - by $88 \%$ (Figure 5).

As of 2019, the net profit of banking institutions in Canada showed a growth of $2 \%$ and amounted to 49.38 billion Canadian dollars. In general, after the financial crisis, the net profit of commercial banks showed a positive trend, but this year the growth was the lowest in 10 years.

All income items of Canadian commercial banks in 2019 showed a positive trend (slightly weaker than last year), except for income from securities transactions, which decreased by $18 \%$ compared to last year (Office of the Superintendent of Financial Institutions, 2020).

According to analysts, profitability was limited by such factors as falling income from capital market instruments and higher reserves for bad loans. Analysts expect earnings per share (EPS) to increase by only $3 \%-4 \%$ in fiscal year of 2019 , according to a survey by Reuters. This would be the slowest growth rate since 2009. According to Gabriel Deschaine, an analyst at the National Bank of Canada, banks' investments to

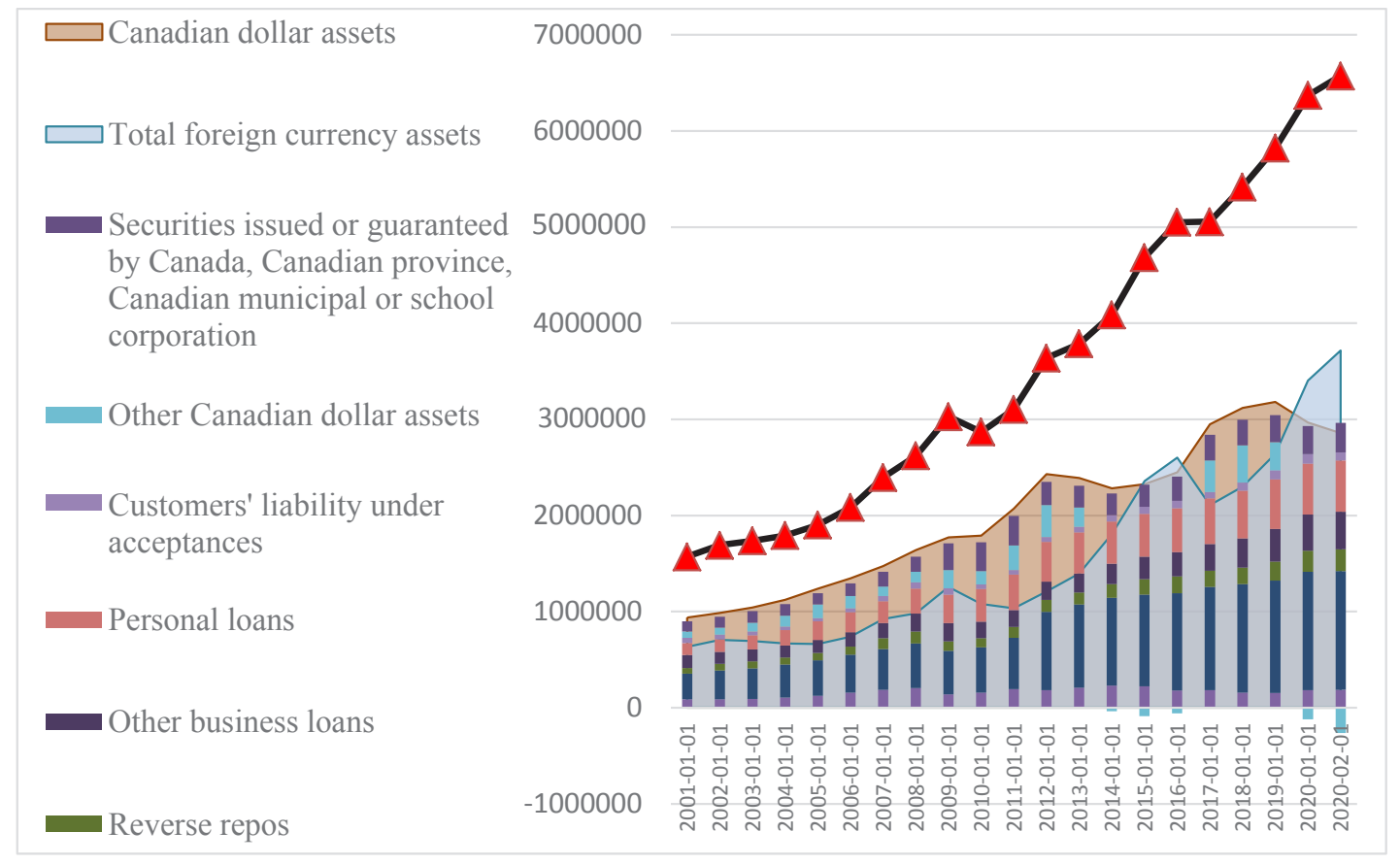

Figure 4. Dynamics of Liabilities and Capital of Banks in Canada, 2001-02.2020

Source: compiled by authors based on materials of the Bank of Canada (Bank of Canada, 2001 a; Bank of Canada, 2020 B) 


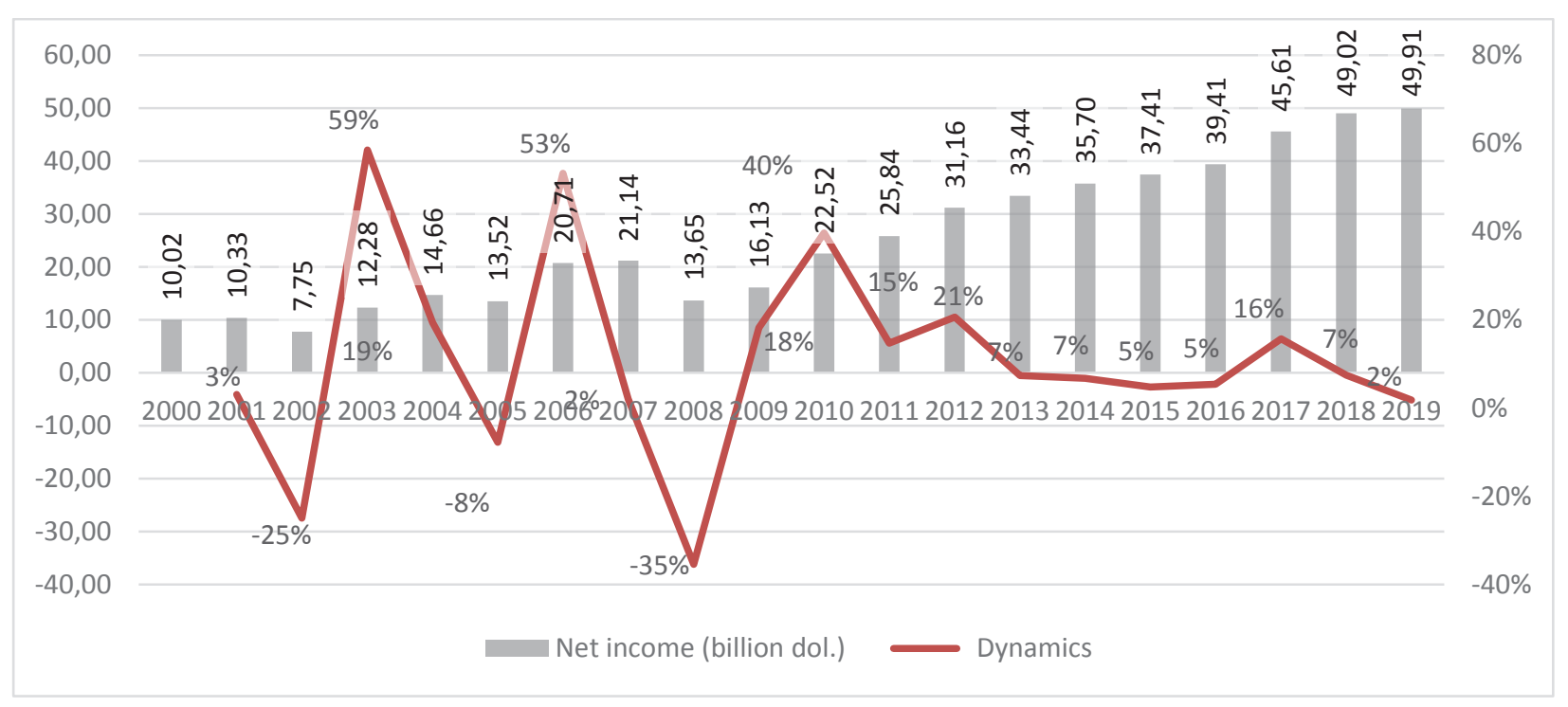

Figure 5. Net Income of Canadian Banks, 2000-2019

Source: compiled by authors based on materials of the Office of the Superintendent of Financial Institutions (Office of the Superintendent of Financial Institutions, 2020)

expand their business in capital markets, especially in the United States, have not yet yielded income, but the cost of this strategy has certainly had an impact. Also, a significant impact on the slowdown in the dynamics of profits of commercial banks could have an increase in the results of 2019 deductions to the reserve for impairment by $27 \%$ caused by consumer insolvency, which in September 2019 increased by 19\% (Saminather, 2019).

Among interest income, the largest share is accounted for loans, $24 \%$ of which are loans to individuals for non-business purposes $(\$ 45.1$ billion,
$+11 \%)$ and $32 \%$ are other loans. Mortgage revenues in 2019 accounted for $25 \%$ of interest income and reached $\$ 47.5$ billion. (Office of the Superintendent of Financial Institutions, 2020).

Another feature that showed a negative trend in 2019 was the non-interest income received from insurance, which amounted to $\$ 4.9$ billion and decreased by $3 \%$ compared to 2018 and account for $6 \%$ of non-interest income (Office of the Superintendent of Financial Institutions, 2020).

Regarding net income in terms of the largest banks, they are distributed according to the data in Figure 6.

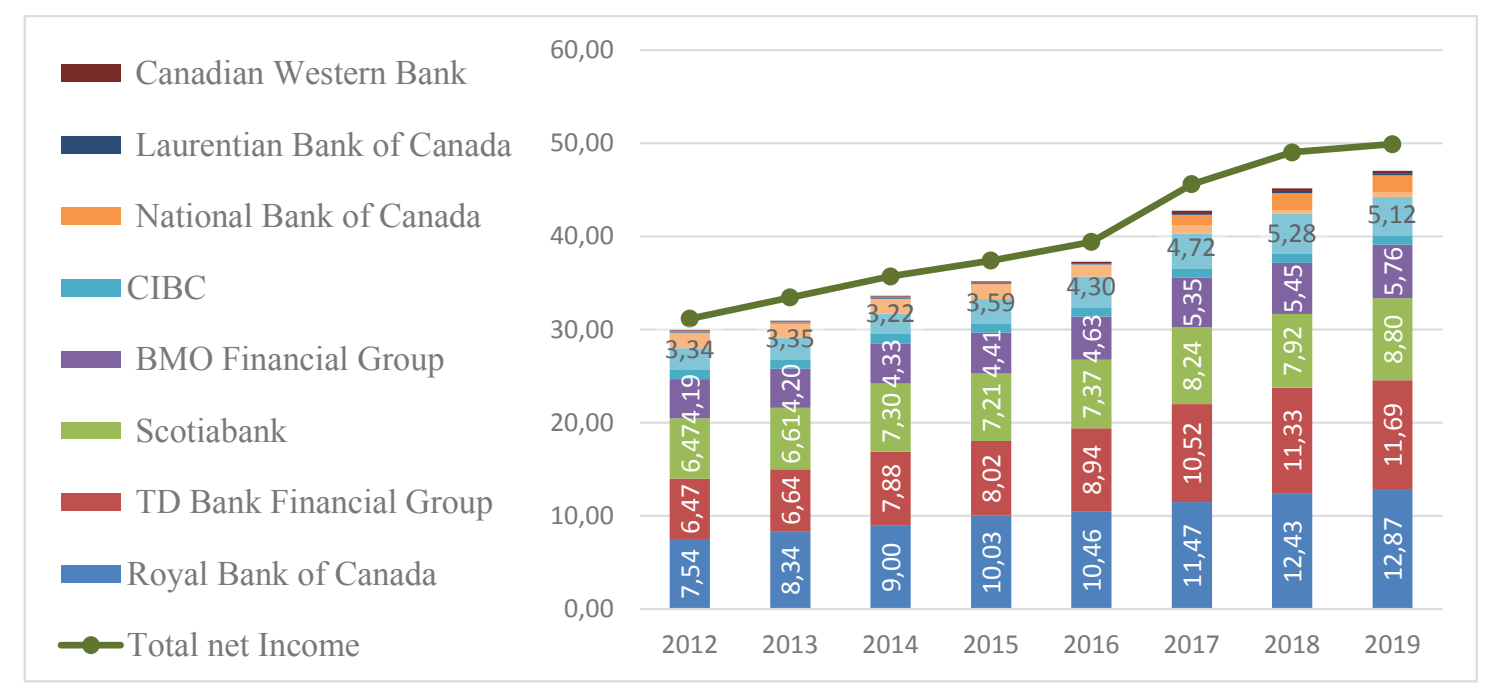

Figure 6. Net Income of the Banking System of Canada in Terms of the Largest Banks, 2012-2019

Source: compiled by authors based on materials of the Canadian bankers association, Office of the Superintendent of Financial Institutions (Canadian bankers association, 2018; Office of the Superintendent of Financial Institutions, 2020) 


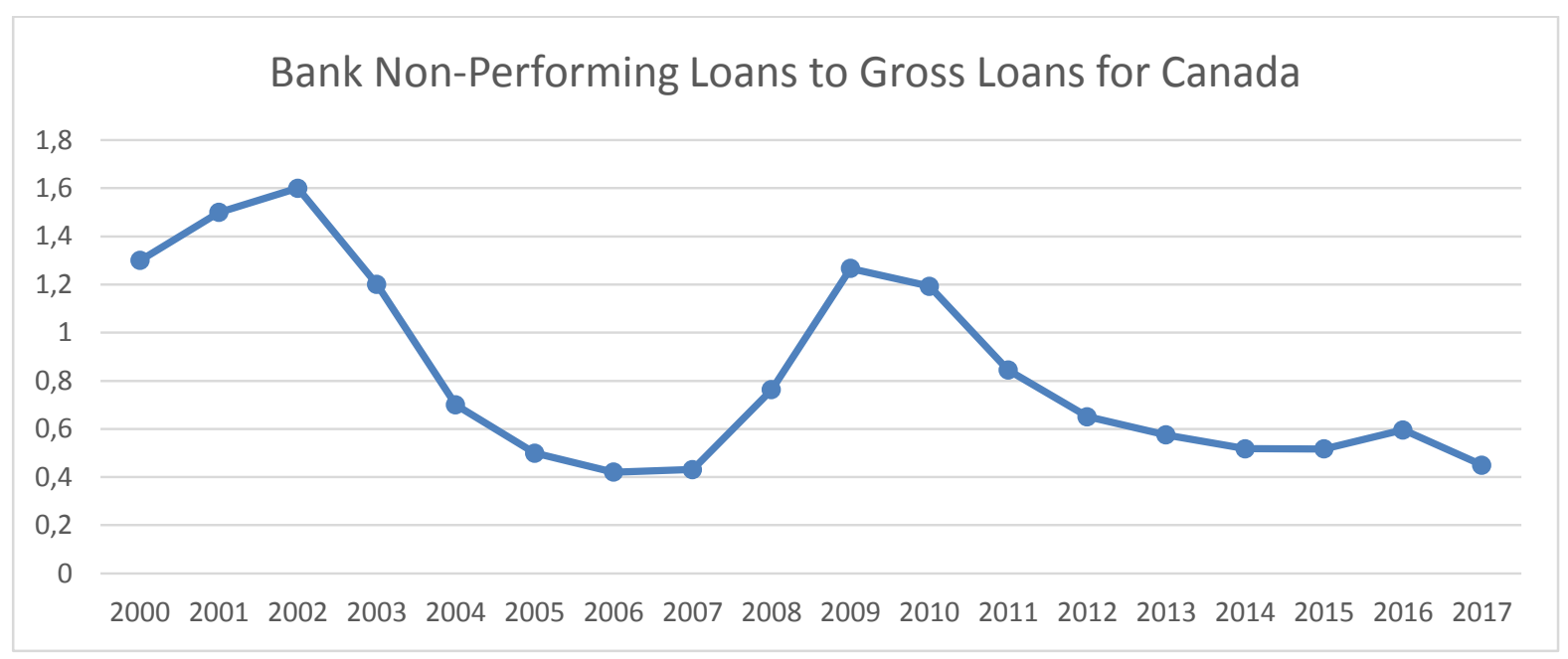

Figure 7. Dynamics of the Share of Outstanding Loans, 2000-2017

Source: compiled by authors based on materials of the World Bank (World Bank, 2019)

\section{The Quality of the Loan Portfolio of Canada's Commercial Banks}

Let us analyze the quality of the loan portfolio of Canada's commercial banks.

In 2002, the highest share of non-performing loans to total gross loans was observed at the rate of $1.26 \%$ (Figure 7).

Since 2009, the Canadian banking sector has shown a significant decrease in the share of outstanding loans $(-0.82 \%$, as of 2017$)$, which indicates a prudent credit policy in the banking sector.

\section{Conclusions}

The Canadian banking system is an efficient commercial banking organization with an almost perfect system of operation. Based on the study, the following conclusions can be drawn:

- it is established that even the period of financial crisis has not affected the number of banks in Canada. Regarding branches, since 2014 their negative dynamics has been observed;

- the assets and liabilities of commercial banks for the study period characterize the positive dynamics. The period of the financial crisis of 2008-2009 reduced the net income of Canadian banks, while 2019 showed an increase of $2 \%$; - the dynamics of the share of outstanding loans in the banking sector since 2009 shows a significant decrease. In general, the dynamics of the main indicators of the Canadian banking system for the period under study indicates their positive dynamics, except for the years of the financial crisis of 2008-2009.

\section{References:}

Bank for International Settlements (2018). Structural changes in banking after the crisis, no. 60. Retrieved from: https://www.bis.org/publ/cgfs60.pdf (accessed 10 July 2020).

Bank of Canada (2020 a). Retrieved from: https://www.bankofcanada.ca/valet/observations/V53006708,V36 935,V53006709,V53006711,V53006712,V53006710,V37324,V36907,V36908,V36905,V36896,V36921,V3692 4,V36926,V36927,V36920,V53006713,V36918,V36919,V53006714,V36933,V36934,V36885,V36884,V36883/ csv?start date $=1980-01-01 \&$ end date $=2020-04-01$ (accessed 10 July 2020).

Bank of Canada (2020 в). Retrieved from: https://www.bankofcanada.ca/valet/observations/V53006715,V530 06716,V36945,V53006717,V53006718,V53006719,V53006720,V53006721,V53006722,V36939,V36965,V3697 1,V36972,V36956,V36968,V36960,V36961,V36962,V36964,V41598372,V53843372,V36938,V36937,V36936/ csv?start_date $=2000-01-03 \&$ end date $=2020-02-01$ (accessed 10 July 2020).

Banks around the World (2019). List of Banks in Canada 2011-2018. Retrieved from: Retrieved from: https://www.relbanks.com/canada (accessed 10 July 2020).

Bordo, M., Redish, A., \& Rockoff, H. (2011). Why didn't Canada have a banking crisis in 2008 (or in 1930, or 1907, or ...)? Retrieved from: https://www.nber.org/papers/w17312 (accessed 10 July 2020).

Booth, L. (2009). The secret of Canadian banking: Common sense? WORLD ECONOMICS, vol. 10, no. 3. Retrieved from: https://www.researchgate.net/profile/Laurence Booth/publication/46547316 The_Secret_of_Canadian_Banking_Common_Sense/links/00b4951a6090 fe60dd000000.pdf (accessed 10 Jūly 2020).

Calmes, C., \& Théoret, R. (2013). Is the Canadian banking system really "stronger" than the US one?". Retrieved from: http://www.cifo.uqam.ca/publications/pdf/2013-03.pdf (accessed 10 July 2020). 
Canadian Bankers Association (2020). Bank branches in Canada. Retrieved from: https://cba.ca/bank-branchesin-canada (accessed 10 July 2020).

Canadian bankers association (2018). Database of domestic banks' financial results fiscal year-end 2012-2017. Retrieved from: https://cba.ca/bank-financial-results-annual (accessed 10 July 2020).

CDIC (2009). Annual Report 2008. Retrieved from: https://www.cdic.ca/wp-content/uploads/2008-annualreport.pdf (accessed 10 July 2020).

CDIC (2015). Annual Report 2014. Retrieved from: https://www.cdic.ca/wp-content/uploads/2014-annualreport.pdf (accessed 10 July 2020).

CDIC (2020). Annual Report 2019. Retrieved from: https://www.cdic.ca/wp-content/uploads/cdic-2019-annualreport.pdf (accessed 10 July 2020).

Doug, A. (2019). Branches Still Pay Off for Canada's Banks Even in the App Era. Journal Bloomberg. Retrieved from: https://www.bloomberg.com/news/articles/2019-12-10/branches-still-pay-off-for-canada-s-banks-evenin-the-app-era (accessed 10 July 2020).

Helgi Analytics (2019). Bank Assets (As \% of GDP) in Canada. Retrieved from: https://www.helgilibrary.com/ indicators/bank-assets-as-of-gdp/canada (accessed 10 July 2020).

Office of the Superintendent of Financial Institutions (2020). Financial Data for Banks. Retrieved from: https://www.osfi-bsif.gc.ca/Eng/wt-ow/Pages/FINDAT.aspx (accessed 10 July 2020).

Ontario Canada (2019). Invest in Ontario. Financial services. Retrieved from: https://www.investinontario.com/ banking\#bring-your-bank (accessed 10 July 2020).

Saminather, S. (2019). Canadian banks are about to report their slowest earnings growth since the financial crisis. Journal Reuters. Retrieved from: https://business.financialpost.com/news/fp-street/rpt-preview-canadian-banksset-to-report-slowest-earnings-growth-since-crisis-on-confluence-of-headwinds (accessed 10 July 2020).

Szmigiera, M. (2020). Number of bank branches in Canada 2000-2018. Retrieved from: https:/ /www.statista.com/ statistics/594343/number-of-bank-branches-canada/\#statisticContainer (accessed 10 July 2020).

World Bank (2020). Bank Non-Performing Loans to Gross Loans for Canada. Retrieved from: ttps://fred.stlouisfed.org/ series/DDSI02CAA156NWDB (accessed 10 July 2020).

World Bank (2019). Bank Non-Performing Loans to total gross loans (\%). International Monetary Fund, Global Financial Stability Report. Retrieved from: https://data.worldbank.org/indicator/FB.AST.NPER.ZS (accessed 10 July 2020). 